\title{
Vehicle Dynamic Simulation Possibilities Using AVL Cruise M
}

\author{
D. NEMES, T. PÁLFI, S. HAJdU \\ University of Debrecen, Faculty of Engineering, Department of Mechanical Engineering
}

Abstract. In most cases, when creating vehicle dynamics simulations, we need software that can speed up model creation and simulation. There are many programs on the market for this purpose, but they have different knowledge and user interfaces. We present in this article briefly introduces the use of one of the market's leading vehicle simulation software, the AVL Cruise M.

\section{Introduction}

Simulation software has been playing an important role in the automotive industry for decades, in our days it has become one of the indispensable tools of development, and there is almost no development range where don't used simulation software. We can significantly reduce development time and cost $[1],[2][3][4][5]$. In this article, we would like to introduce the simulation capabilities and use of AVL Cruise M software, a product of one of the world's largest companies developing propulsion systems [6][7].

In addition to the vehicle industry, AVL Cruise software is used by many research teams and knowledge centers. In this chapter, we will briefly present the potential of the software through their research.

The research of Hungarian universities focused on the comparison of different hybrid drive line. The [8] This article investigates the fuel consumption and emissions of different drives based on different driving cycles. The [10] study, supplementing the previous one, deals with the selection of the drive line according to the application requirements.

Researchers at a university in Romania have converted and tested an internal combustion engine driven car into an AVL environment [11].

We can be used to select gear ratios [12],[13][14], and optimizing gear selection strategies for adaptive transmissions [15][16][17][18] or to align the engine with the transmission [19],[20].

Several studies focus on driving chain analysis based on different driving cycles [21][22][23][24][25], and comparison of driving cycles [21][26][27][28]. We can simulate consumption in different traffic situations [3][13][24][29]. The most important goal of development today is to reduce of the CO2 emissions [23][30][31][32][33][34][35][36][16] or reduction of harmful substances [37]. This can be done by selecting an optimal driveline [12][38][39][40] or by upgrading an existing one 
[14][41][42][43]. Other researchers have investigated the possibility of reducing torsional vibrations [44], or reducing the noise of driveline [45] studied with the program.

\section{The structure of the program}

To get to know the software, it is indispensable to get acquainted with its interface. The program is completely modular. This means that without much programming knowledge, it is possible to build a model by arranging and connecting the elements. Since it is a special purpose software, its components also involve more complex tasks[17],[18]. While, for example, the MATLAB Simulink toolbar embodies basic physical processes with abstraction, the AVL Cruise M typically includes specific vehicle components. For the sake of simplicity, these elements are divided into separate main groups. To ensure the smooth flow of material, energy and signal, the software allows only the right elements to be joined, thus reducing the number of errors of principle. These elements are shown in Figures 1-2.

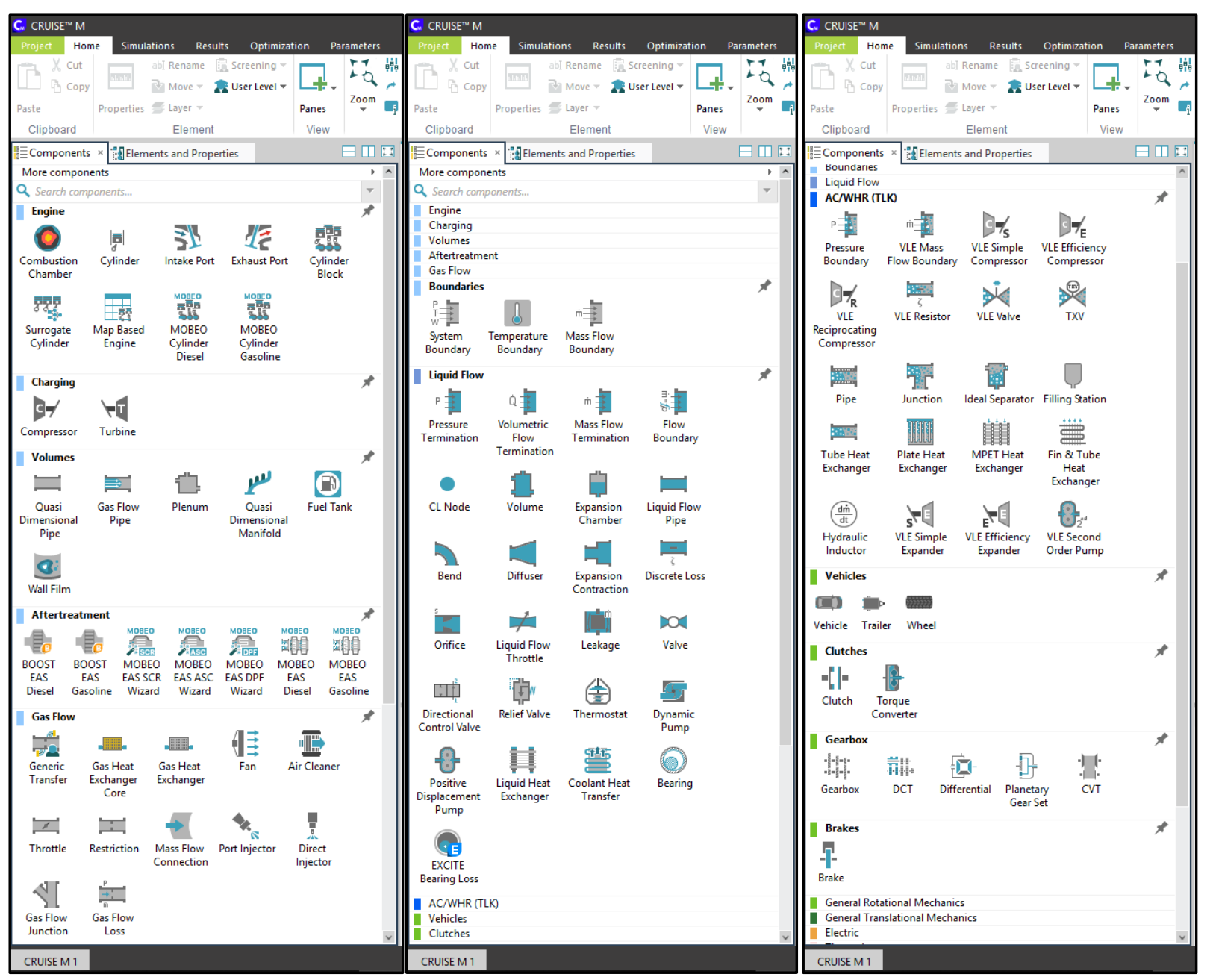

Figure 1. AVL Cruise M Toolbar 1 


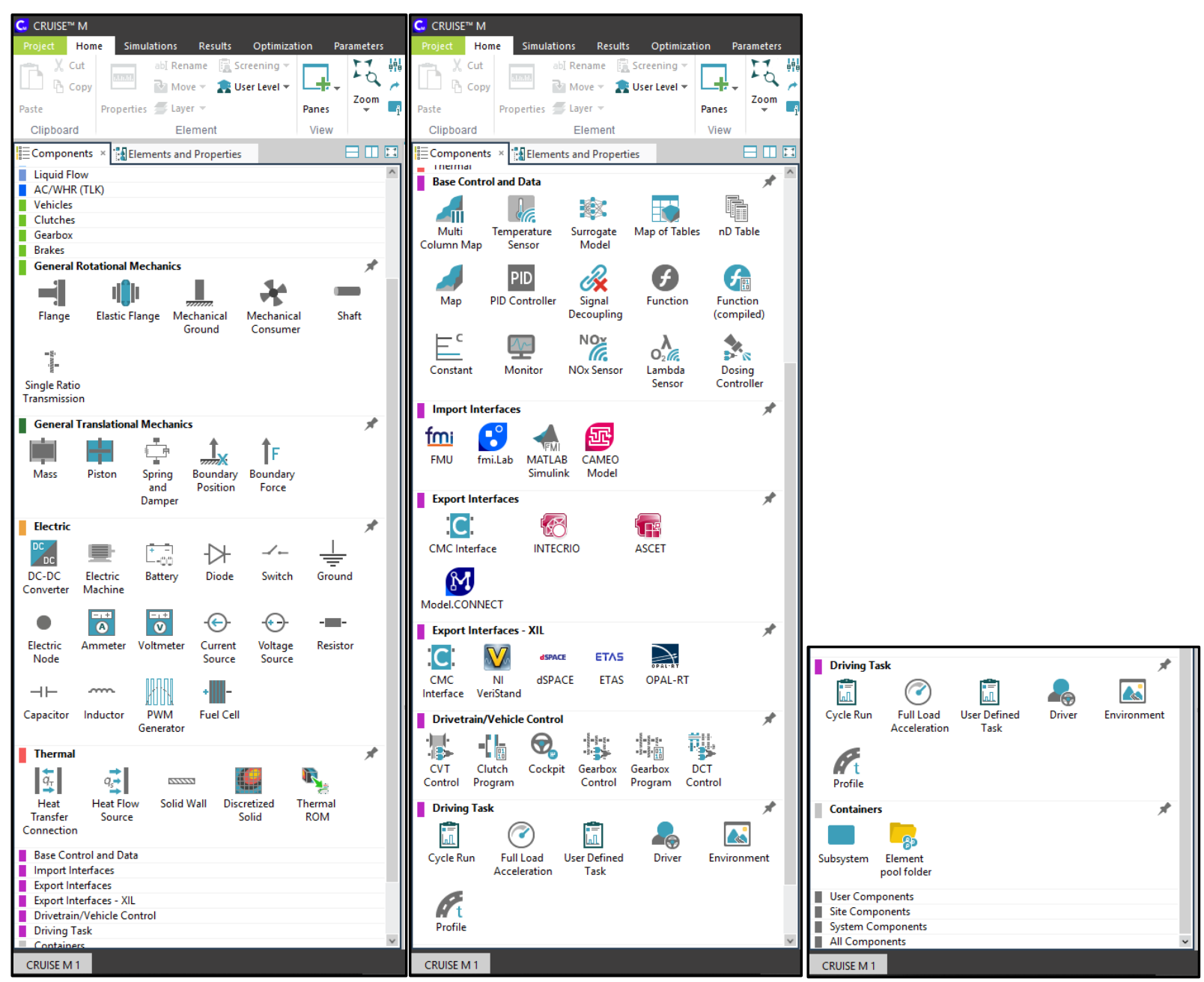

Figure 2. AVL Cruise M Toolbar 2

\section{BUILDING A MODEL}

The structure of the model is formed by the proper connection of elements already mentioned. When it comes to assembling a vehicle, beside the wheels, brakes, engine and bodywork etc., it is important to specify the driving cycle and track details as well as the environment. The definition of environment includes the temperature, pressure and composition of air. The course can be defined in 3-dimension space with varying frictional conditions for example with CarSim. This allows us to test stability control systems in slippery road conditions. AVL Cruise M is able to cooperate with several other programs. With these additions, we have even more simulation possibilities.

\subsection{Example model}

Let us look at a simple throttle simulation for an overview of how the software works. This requires an element with flow resistance and a pressure difference of more than zero between the two connection points of the element. When starting the simulation, air starts to flow from the higher pressure side to the lower pressure side. This simple simulation also has several setup parameters. One of these is the duration of simulation, which can be set to a fixed value or infinite. In the latter case, the simulation 
can be stopped only by the stop command. The gradual build-up of the mass flow may be approximated, or even completely neglected. It is important to note here that the inertia multiplier should be set to best approximate the measured data. This parameter is used to set the initial steepness of the time - mass flow diagram. The characteristic cross-section should be considered as a calibration variable, not a true geometric dimension. This is because the flow conditions of the element are also influenced by the resistance factor. The software allows us to specify two different resistance values in the two flow directions. It is important to note that if we do not simulate transient processes, the mass flow will always stabilize in the second computation step and increase linearly until then. The structure of the model and the results of simulation are shown in Figure 3.

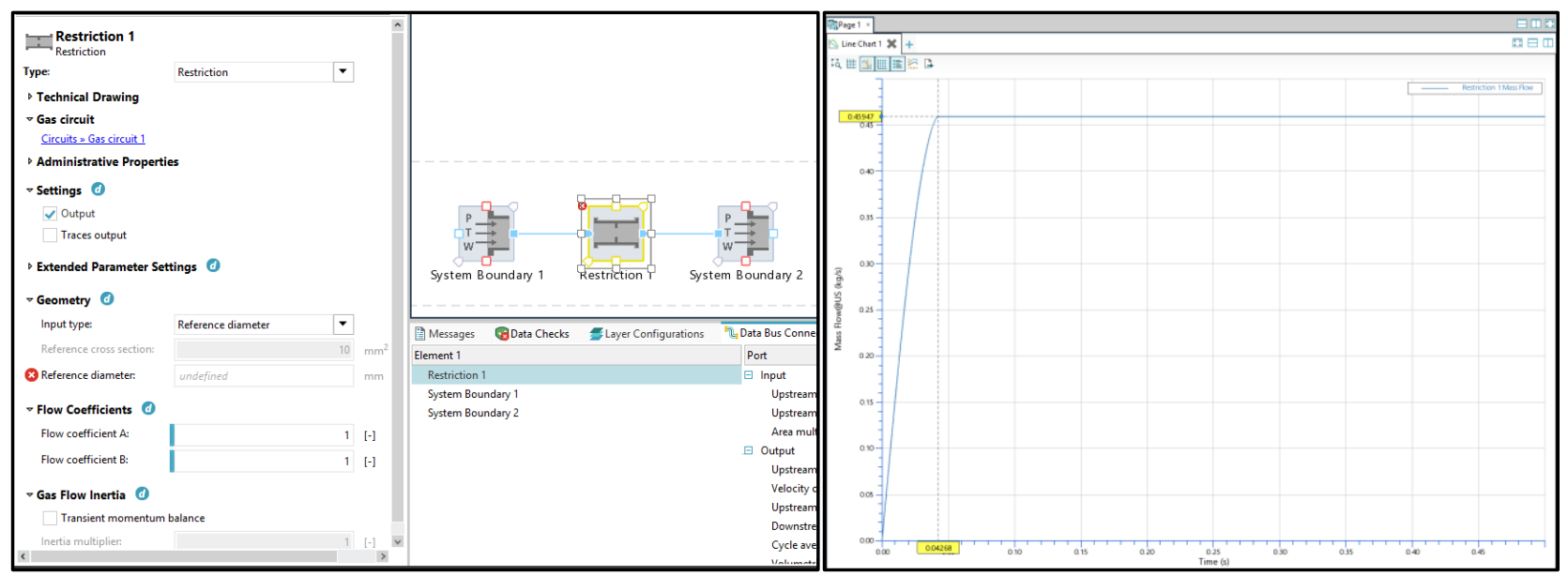

Figure 3. Structure of a simple throttle and the time - mass flow diagram of the throttle

The software automatically notifies us if an element is missing a parameter. In the actual case, we need to specify the reference diameter or cross-section of the throttle. The ElementsandProperties tab shows all elements. If selecting one, its properties can be set. It is also available by double-clicking the element. On the Settings tab, among other things, we can set the simulation time and interval. Once the settings are done, we click Run on the Simulations ribbon to complete the calculation. For security reasons, the software requests to save the project before simulation. The Results ribbon has several tools for evaluating the simulation. Using these considerations, a complete vehicle can be built. The length of this article does not allow a detailed description of how to calibrate the parameters, so let us look at the structure of a built-in vehicle model, which is shown in Figure 4.

As can be seen in this model of vehicle equipped with an internal combustion engine, beside engine, gearbox, wheels, brakes, etc., there is an object for adjusting the drive cycle and an element for generating a full load condition. The latter appears dimly. This means that it is deactivated, therefore the simulation would run with the preset driving cycle. The engine in this case is a pre-built engine model, for which only the characteristics of the engine need to be specified. 


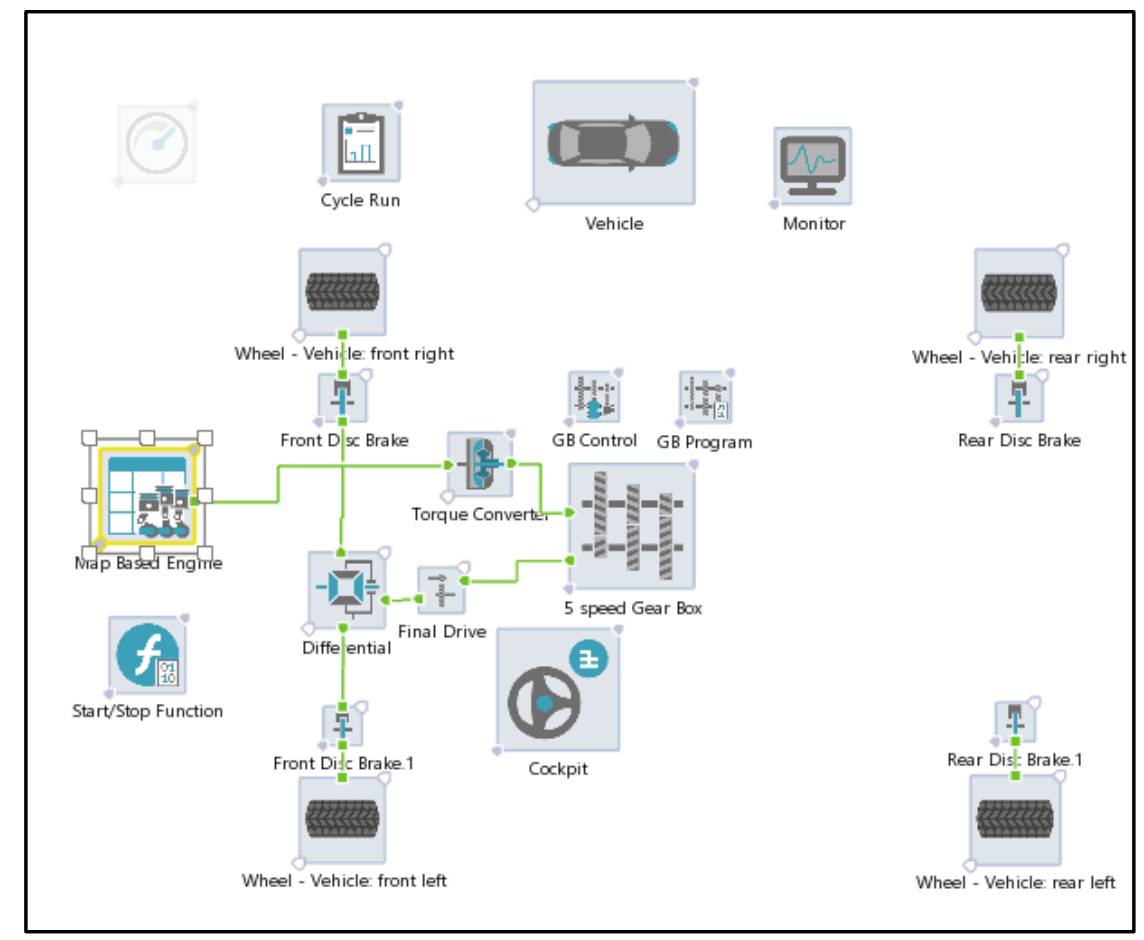

Figure 4. Example vehicle structure

\section{Detailed description of example model Elements}

\subsection{Wheels}

The dynamic modeling of the wheels can be simplified with the simple Coulomb friction model and the moment of inertia of the wheel. Measurements show that the frictional force between the wheel and the road is also highly dependent on tire pressure, radius and width. For the sake of completeness of the dynamic model, the wheel's rolling resistance is also need to be considered. For modeling a wheel, the Pacejka tire model is generally applied. Since Cruise M calculates from measurement data, it defines the characteristics of the wheel also with characteristic curves and constants. An example of this is shown in Figure 5.

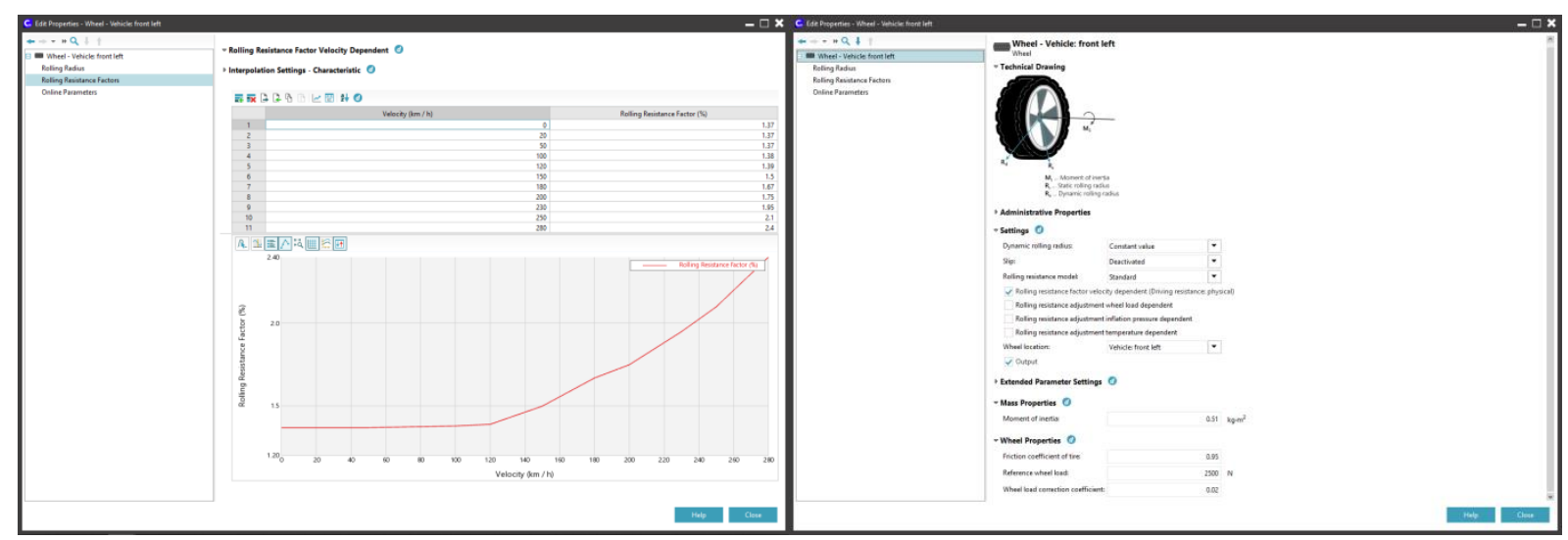

Figure 5. Data of wheel model 


\subsection{Brakes}

If modeling the brakes, much less parameters need to be set. These are the inertia and geometric proportions of the brake. The braking force of the wheels is calculated from the actual brake pressure. To control brakes, another module is used. The technical diagram helps to understand the parameters. The brake parameters are shown in Figure 6.

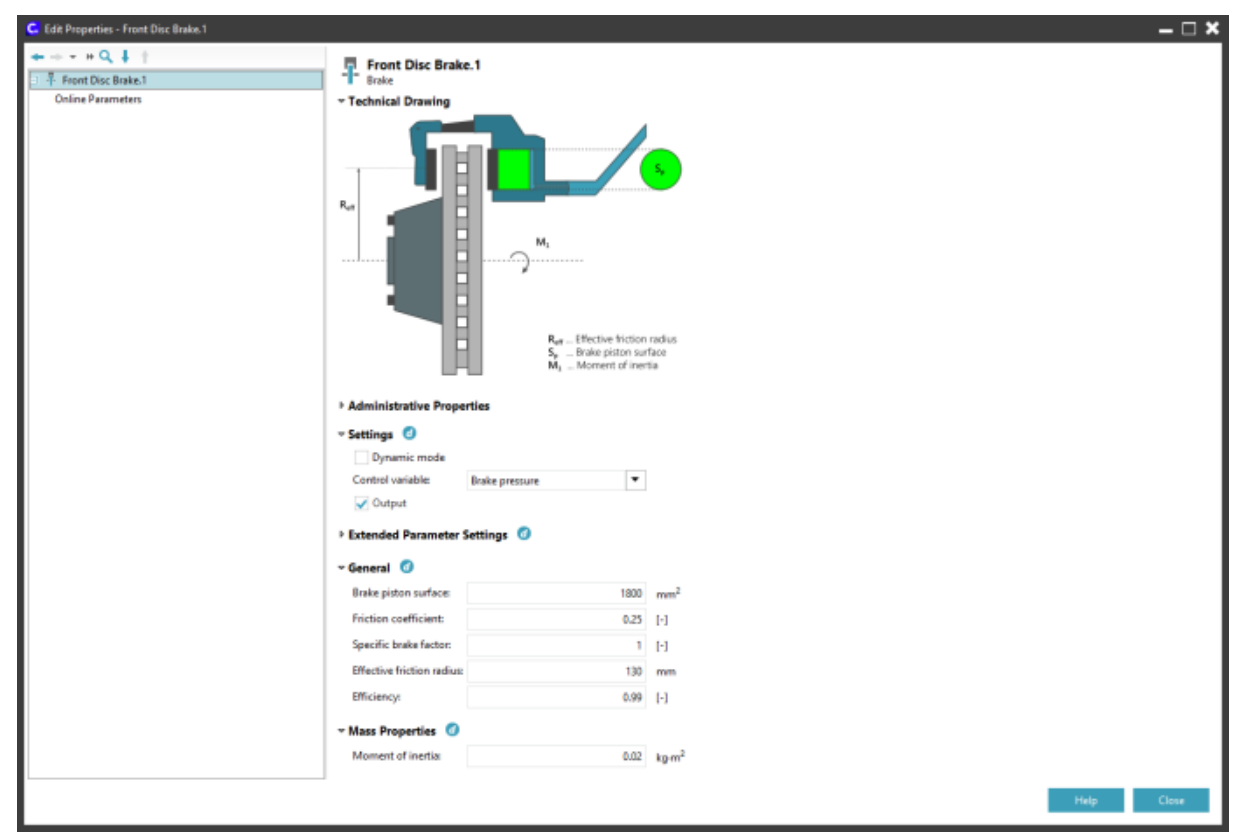

Figure 6. Brake parameters

\subsection{Differential, final gear ratio, transmission}

In the case of differential, the moment of inertia of the input and two output sides and the torque distribution between the two output sides can be given. It is possible to lock the differential. In practice, the torque distribution and differential locking is controlled on-line. Beside final gear ratio we can give additional moments of inertia as well as efficiency. The transmission can be set to any number of gears. Gear ratios as well as inertia and efficiency of the input and output sides can be given.

\subsection{Hydrodynamic clutch}

In this model, a hydrodynamic clutch is applied. Its characteristics also need to be defined by a curve for quick simulation. The inertia of mechanical rotating elements can be also here adjusted by their moment of inertia. An example of this is shown in Figure 7. 


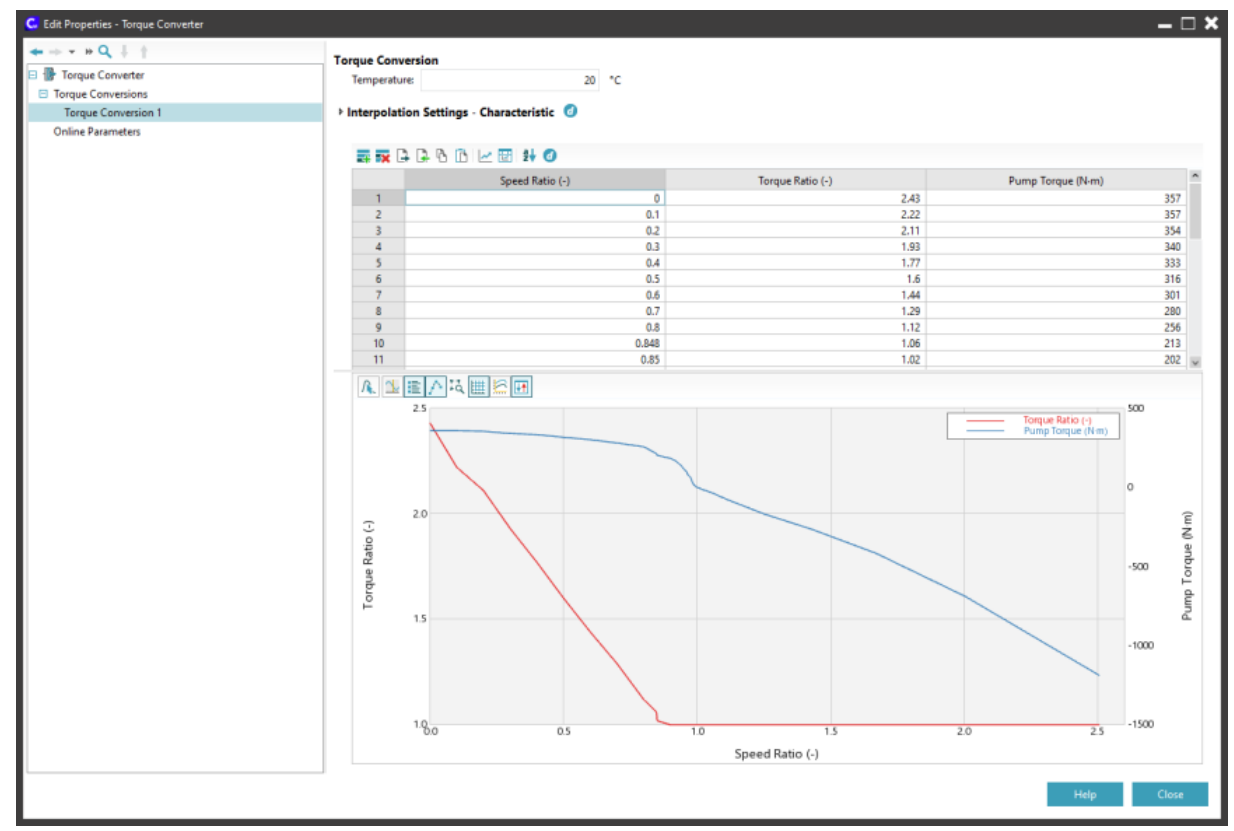

Figure 7. Hydrodynamic clutch characteristic curve

\subsection{Engine}

The software has a built-in engine module based on characteristic curves, so the software does not calculate by the operational data of the engine in the example (combustion process, pre-ignition, cylinder pressure build-up, heat transport).If not only the characteristic of the drive chain is to be monitored, a detailed internal combustion engine model can be also created. The characteristics of the engine applied can also be accessed and changed within the settings. Figure 8.a-d shows the characteristic curves and maps.

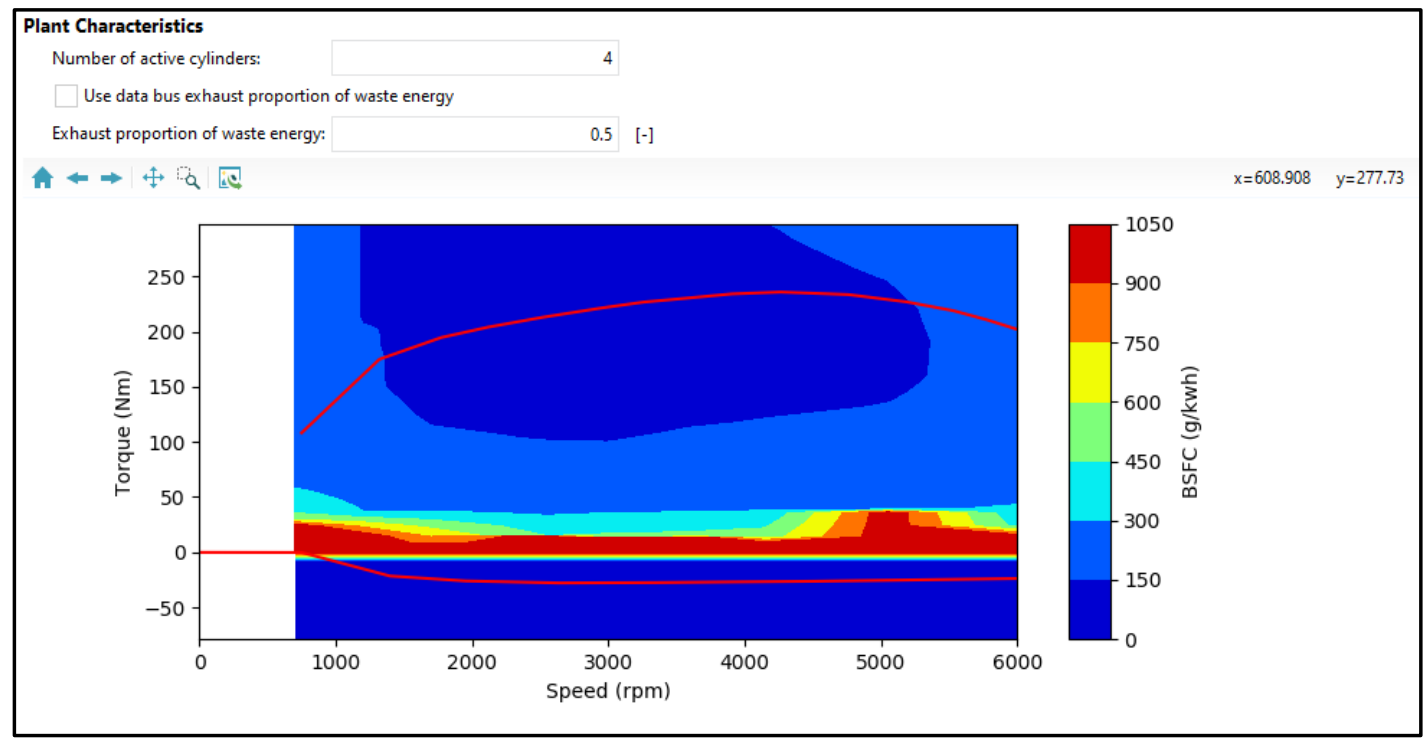

Figure 8.a Torque - engine speed - consumption $[\mathrm{g} / \mathrm{kWh}]$ map of the engine 
International Journal of Engineering and Management Sciences (IJEMS) Vol. 5. (2020). No. 2

DOI: 10.21791/IJEMS.2020.2.35.

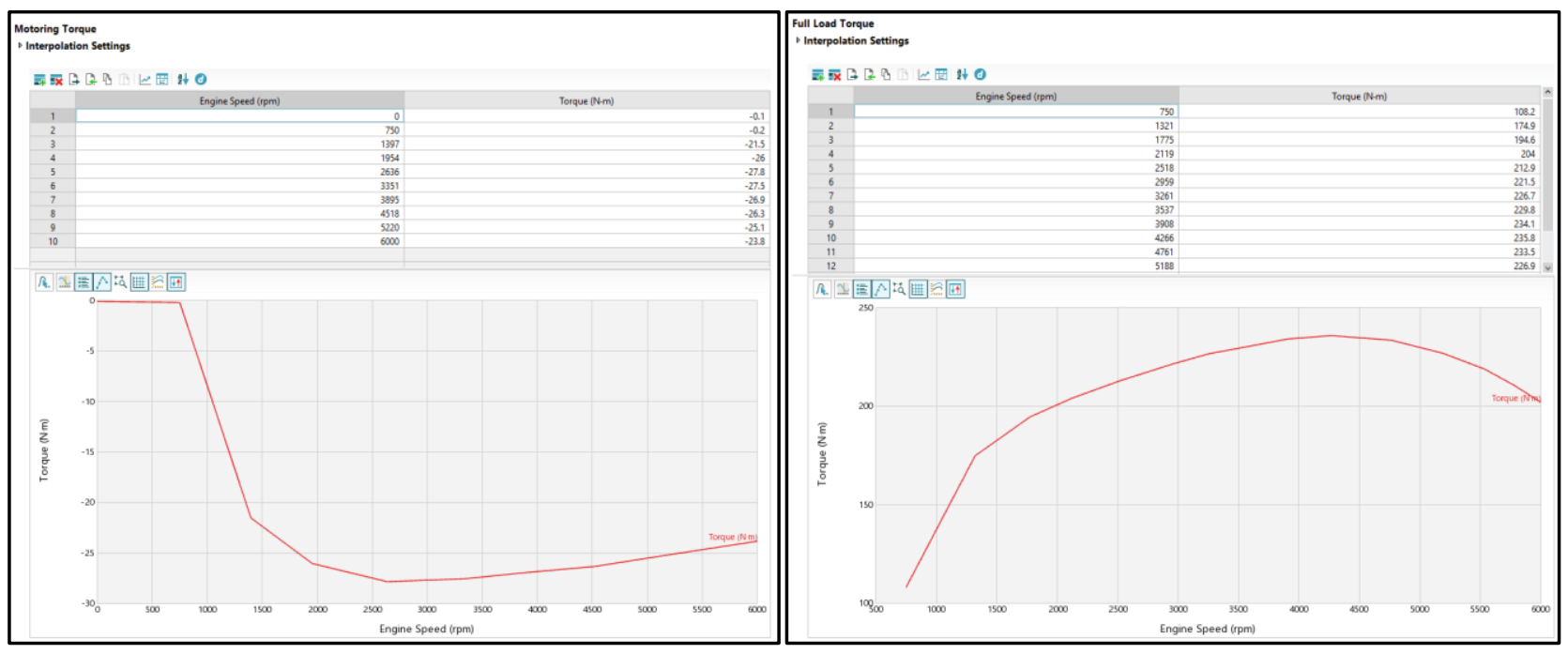

Figure 8.b-c Engine brake and full load torque curves

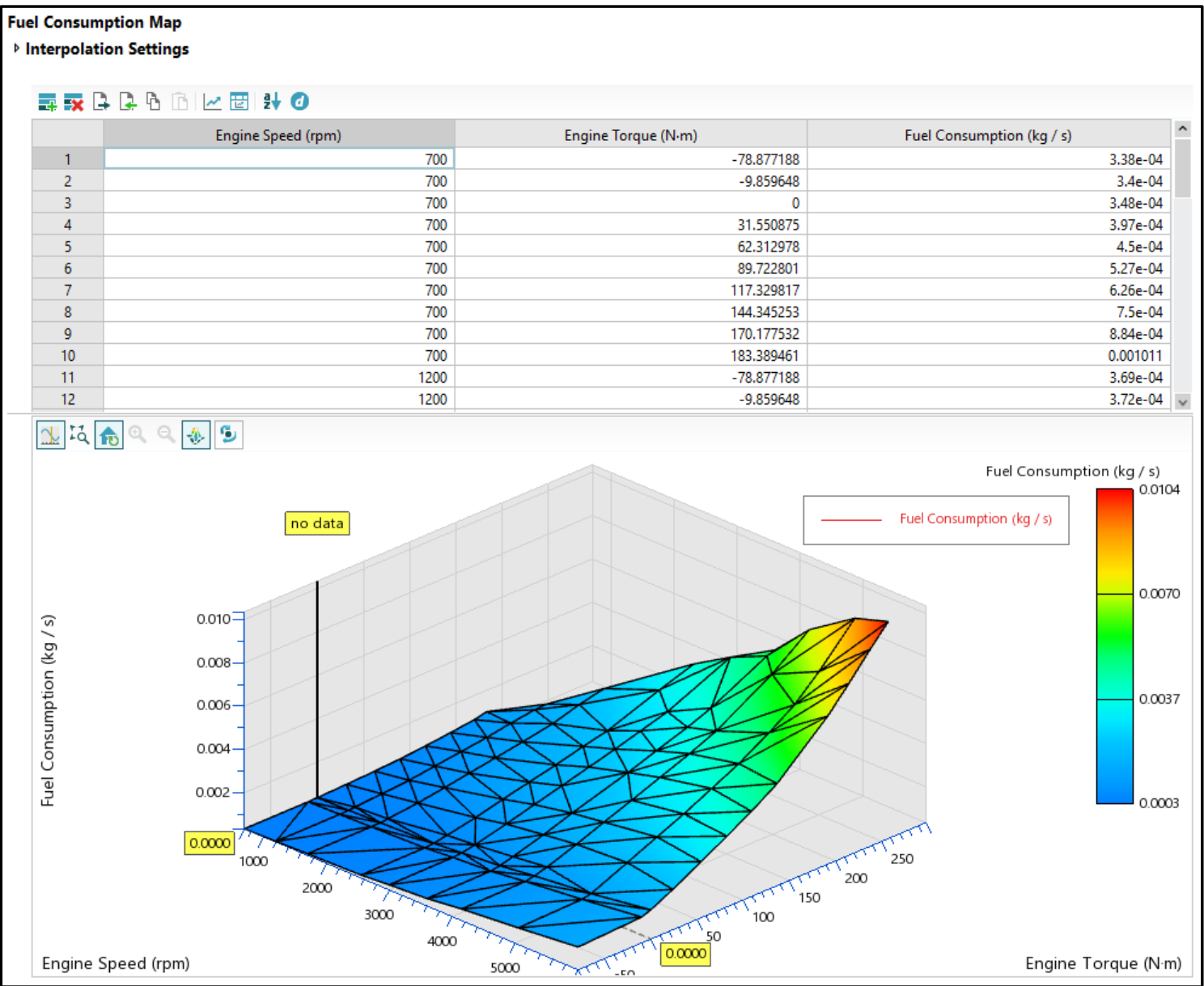

Figure 8.d Engine speed - torque - consumption [ $\mathrm{kg} / \mathrm{s}]$ map of the engine 


\subsection{Vehicle}

Modeling the weight of a vehicle requires the mass of the passengers and fuel to be considered. These masses influence the overall driving dynamics. The vehicle parameters are shown in Figure 11-12.

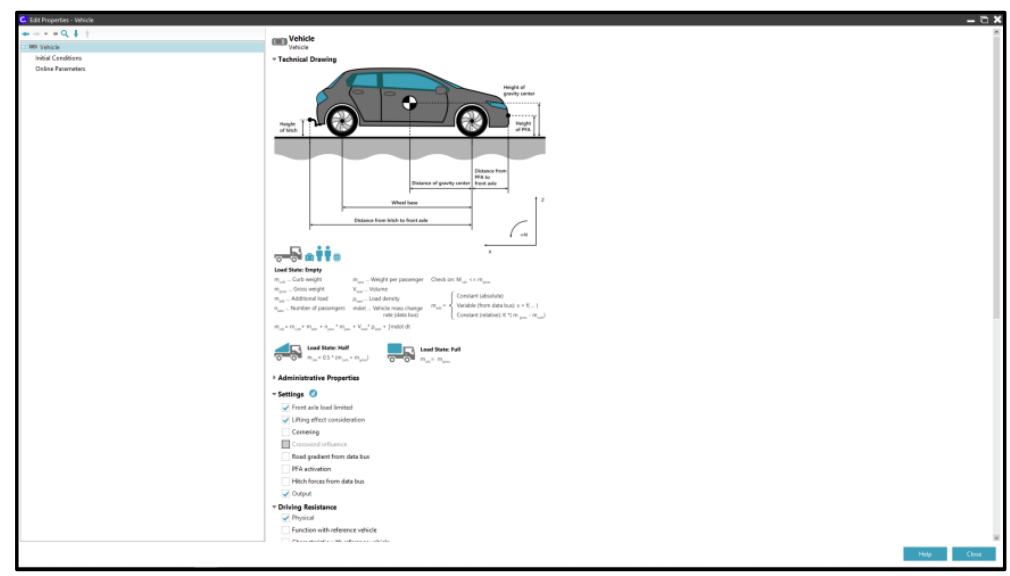

Figure 11. Technical scheme of vehicle setup

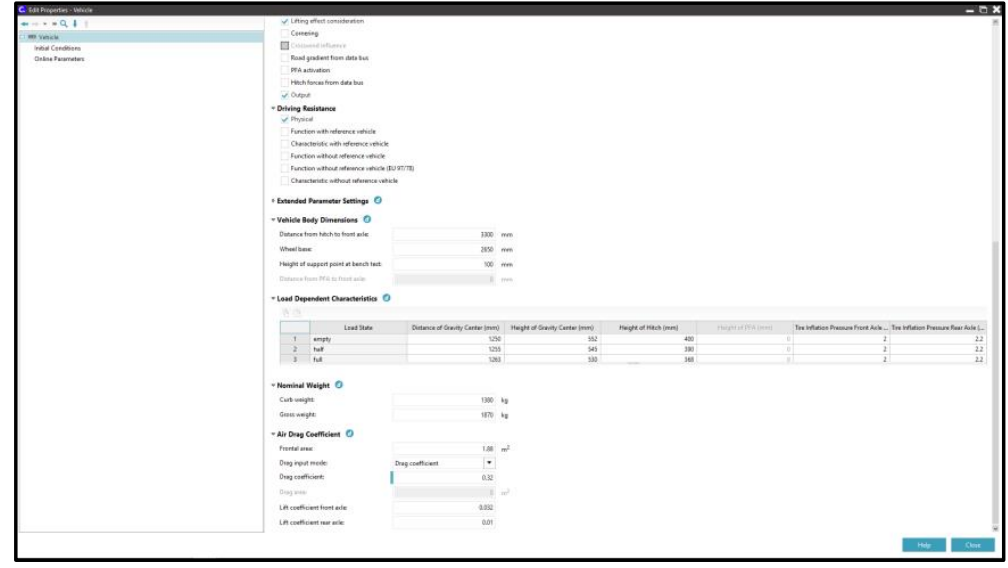

Figure 12. Vehicle parameters

\subsection{Control}

In control settings, characteristic curves of brake pedal and accelerator pedal can be defined, too. Automatic transmission shifting periods are given by limits, but we have the possibility to apply a complex control strategy. In today's modern vehicles, this is a combination of a genetic algorithm and a program based on Fuzzy logic.

\subsection{Driving cycle}

When creating a driving cycle, the relevant data are often only the change of road surface elevation and the change of the desired speeds over time. The driving cycle in the example is shown in Figure 13. The most simulated and measured data are emissions, fuel consumption and efficiency. These also significantly depend on the driver. In this case, the driver is a PI controller. The driving style - peaceful or aggressive - can be defined by adjusting the parameters of the controller. Within the driving cycle, 
we can set variable environment parameters. This is very useful when the composition, temperature and humidity of air changes due to the changing terrain. In the example simulation, these are given with constant values.

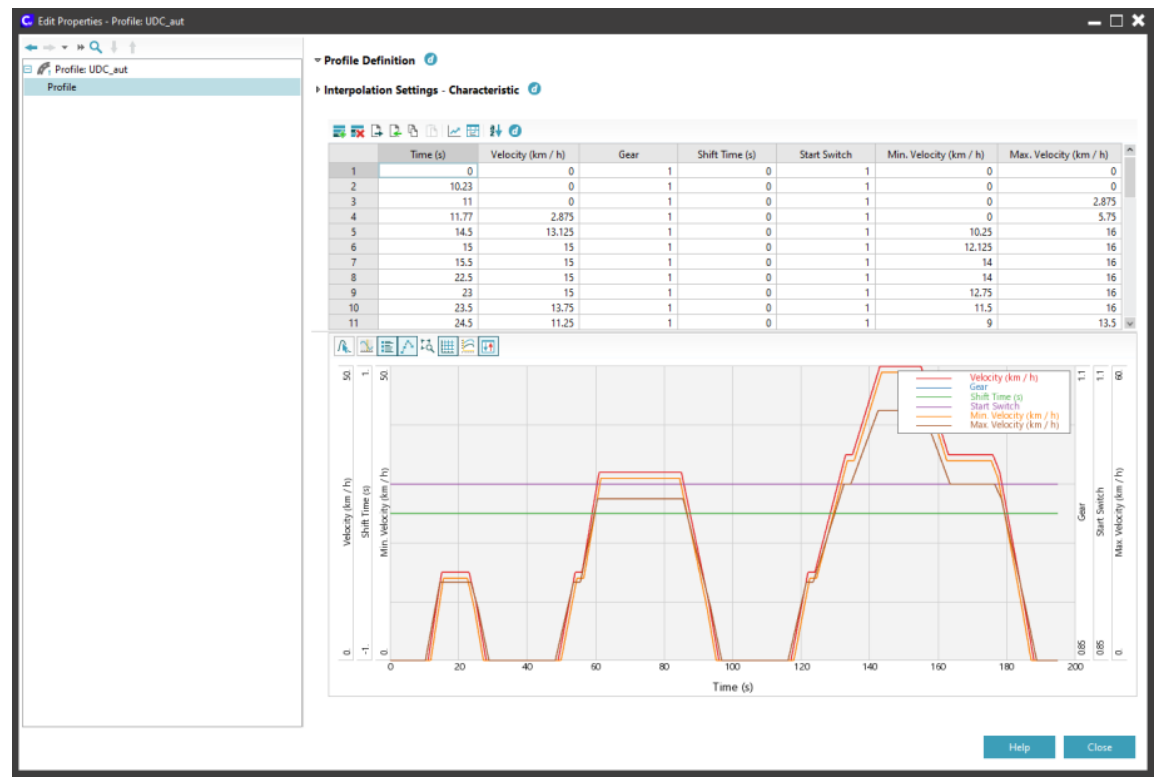

Figure 13. Driving cycle

\subsection{Results of simulation}

During simulation it is possible to monitor the evolution of the parameters in graphs, tables and displays. An example of this is shown in Figure 14.

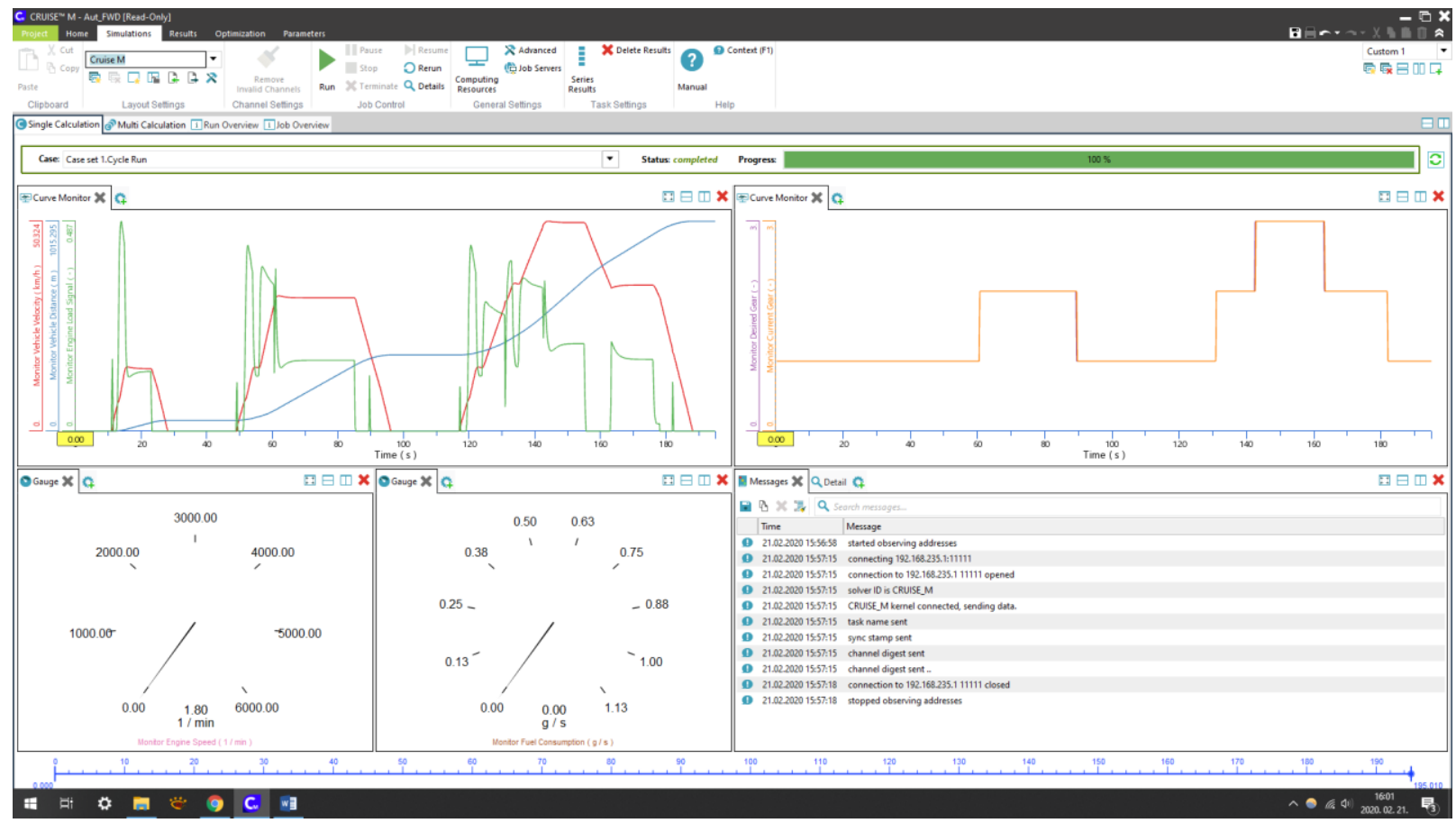

Figure 14. Displaying results during simulation 
The results can be evaluated and exported on the Results tab. This is illustrated in Figure 15.

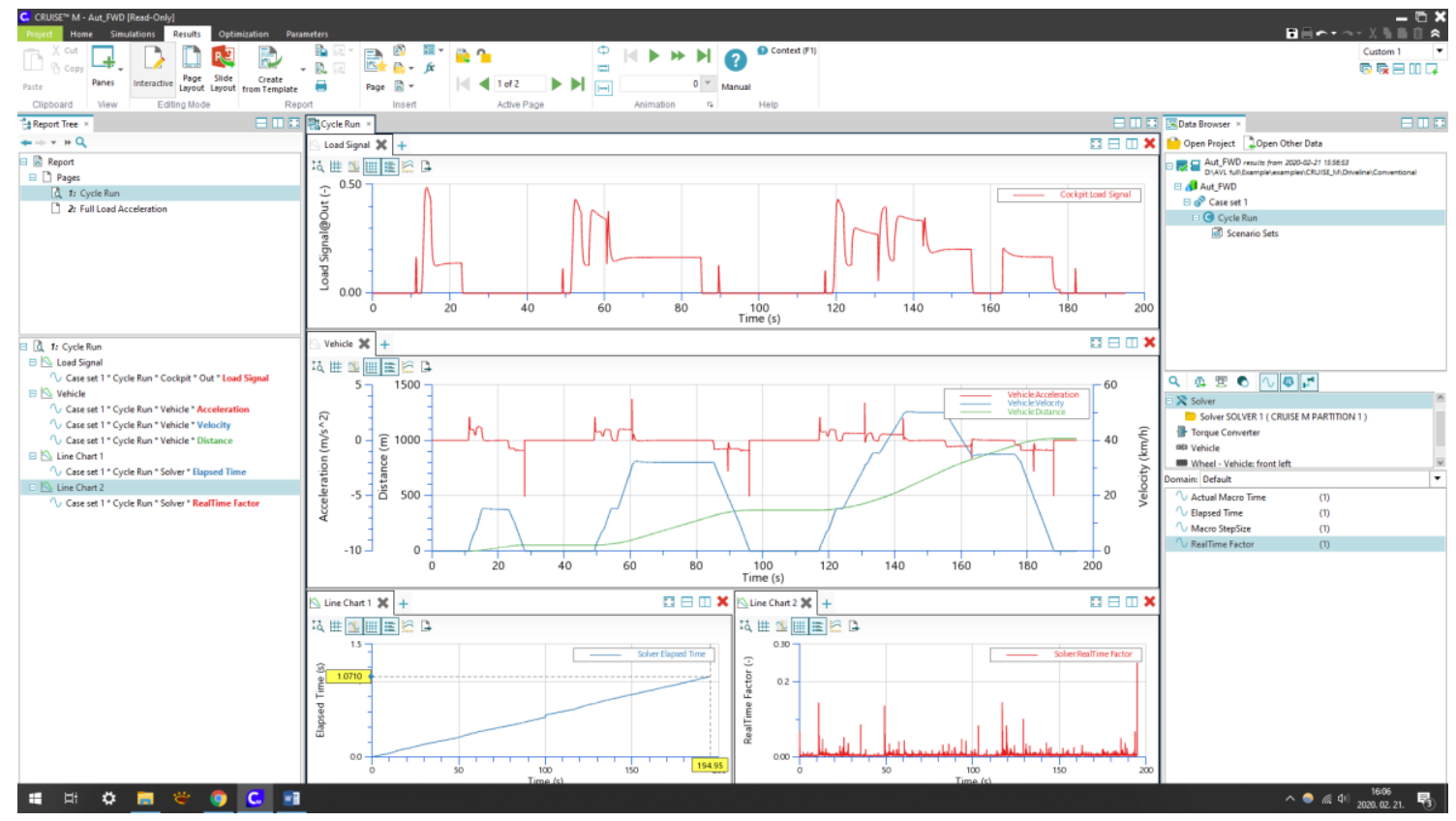

Figure 15. Displaying results on the Results tab

It can be seen in the figure that a 200 seconds simulation of a model of this complexity ran in just over a second on an average computer. This is due to the fact that the model bases the characteristics of the elements on measurement curves and maps. If simulating the internal combustion engine in more detail in the model, the simulation of heat flows and air flows requires high computing power, but it is much faster than any other model based on mathematical calculations.

\section{Conclusion}

The model above perfectly reflects the Cruise M's zero-dimensional simulation system, where complex processes are not modeled with calculations or in 3-dimension space, but data are extracted from characteristic curves and then they are compared. At a given vehicle weight, speed and accelerator pedal position, the power of the engine can be read from the engine's characteristic curves. From this, the torque accelerating the drivetrain can be determined. We can then calculate the acceleration force of the vehicle from the inertia values of the drivetrain and the grip characteristics of the tire. It follows that the creation of an accurate vehicle model requires many measured data and calibration. After adequate measurements and calibrations, various configurations can be properly modeled.

\section{Acknowledgements}

The research was financed by the Thematic Excellence Programme of the Ministry for Innovation and Technology in Hungary (ED_18-1-2019-0028), within the framework of the (Automotive Industry) thematic programme of the University of Debrecen.

The paper is made by the support of "AVL Advanced Simulation Technologies University Partnership Program". 
International Journal of Engineering and Management Sciences (IJEMS) Vol. 5. (2020). No. 2

\section{References}

[1] W. Hasewend, "AVL CRUISE - Driving Performance and," ATZ worlwide, vol. 103, no. 5, pp. 10$13,2001$.

[2] A. Iorga, "Road vehicle simulation using AVL Cruise," no. 25, 2016.

[3] F. O. F. Mechanics, "Simulation of a Passenger Car Performance and Emissions Using the AvlCruise Software,” pp. 95-98, 2011.

[4] AVL - Advanced Simulation Technologies, "Cruise vehicle system analysis, AVL Cruise - Vehicle System and Driveline Analysis, AVL Product description," 2009.

[5] S. A. Evangelou and W. Shabbir, "Dynamic modeling platform for series hybrid electric vehicles," IFAC-PapersOnLine, vol. 49, no. 11, pp. 533-540, 2016, doi: 10.1016/j.ifacol.2016.08.078.

[6] W. Hasewend, "Avl Cruise," ATZ - Automob. Zeitschrift, vol. 103, no. 5, pp. 382-392, 2001, doi: $10.1007 / \mathrm{bf03224378.}$

[7] AVL, “AVL PRODUCT DESCRIPTION CRUISE,” Graz, 2009.

[8] Bári Gergyely - Varga Dávid - Kocsis Bence - Trencséni Balázs - Dr. Ailer Piroska, "Hibridelektromos hajtáslánc koncepciók összevetése objektív szempontok alapján," Jövő járműve, pp. 46-52, 2014.

[9] R. Y. Ilimbetov, V. V. Popov, and A. G. Vozmilov, "Comparative analysis of 'NGTU - Electro' electric car movement processes modeling in MATLAB Simulink and AVL Cruise software," Procedia Eng., vol. 129, pp. 879-885, 2015, doi: 10.1016/j.proeng.2015.12.117.

[10] Varga Dávid - Kocsis Bence - Trencséni Balázs - Dr. Ailer Piroska, “Hibrid-elektromos hajtáslánc koncepciók szubjektív tulajdonságai," Jövő járműve, pp. 82-87, 2014.

[11] C. C. Cioroianu, D. G. Marinescu, A. Iorga, and A. R. Sibiceanu, "Simulation of an electric vehicle model on the new WLTC test cycle using AVL CRUISE software," IOP Conf. Ser. Mater. Sci. Eng., vol. 252, no. 1, p. 012060, Oct. 2017, doi: 10.1088/1757-899X/252/1/012060.

[12] J. Ma, "Parameter optimal design and Simulation of Power System of Electric Vehicle Based on AVL-CRUISE," J. Phys. Conf. Ser., vol. 1187, no. 3, 2019, doi: 10.1088/1742$6596 / 1187 / 3 / 032029$.

[13] Y. Yang, H. Zhao, and H. Jiang, "Drive train design and modeling of a parallel diesel hybrid electric bus based on AVL/cruise," EVS 2010 - Sustain. Mobil. Revolut. 25th World Batter. Hybrid Fuel Cell Electr. Veh. Symp. Exhib., vol. 4, pp. 75-81, 2010.

[14] J. Soldo, V. Ranogajec, B. Škugor, and J. Deur, "AVL CRUISE Model-based Optimisation of Shift Scheduling Maps for a Parallel Hybrid Electric Vehicle," AVL Int. Simul. Conf. 2017, 2017.

[15] E. Kural and B. A. Güvenç, "Integrated Adaptive Cruise Control for parallel hybrid vehicle energy management," IFAC-PapersOnLine, vol. 28, no. 15, pp. 313-319, 2015, doi: 
International Journal of Engineering and Management Sciences (IJEMS) Vol. 5. (2020). No. 2

10.1016/j.ifacol.2015.10.045.

[16] C. Geng, X. Jin, and X. Zhang, "Simulation research on a novel control strategy for fuel cell extended-range vehicles," Int. J. Hydrogen Energy, pp. 408-420, 2019, doi:

10.1016/j.ijhydene.2018.04.038.

[17] M. A. Naya, D. Dopico, J. A. Perez, and J. Cuadrado, "Real-time multi-body formulation for virtualreality-based design and evaluation of automobile controllers," Proc. Inst. Mech. Eng. Part KJ. Multi-body Dyn., vol. 221, no. 2, pp. 261-276, Jun. 2007, doi: 10.1243/1464419JMBD74.

[18] Z. Kong, D. Pi, X. Wang, H. Wang, and S. Chen, "Design and Evaluation of a Hierarchical Control Algorithm for an Electric Active Stabilizer Bar System," Strojniški Vestn. - J. Mech. Eng., vol. 62, no. 10, pp. 565-576, Oct. 2016, doi: 10.5545/sv-jme.2016.3381.

[19] F. Du, Z. W. Guan, C. H. Liu, and Y. S. Wan, "Matching research between engine and transmission of vehicle based on AVL-Cruise," in Proceedings of the 2015 International Conference on Power Electronics and Energy Engineering, 2015, no. Peee, pp. 89-92, doi: 10.2991/peee-15.2015.24.

[20] L. Mihon, A. Negoitescu, A. Tokar, and D. Ostoia, "Motor and Vehicle Optimization Process Modeling By Using the Avl Cruise in Standard," Ann. Fac. Eng. Hunedoara - Int. J. Eng., pp. 83-86, 2011.

[21] A. R. SIBICEANU, A. IORGA, V. NICOLAE, D. G. MARINESCU, and C. CIOROIANU, "Considerations on adapting the new WLTC test cycle for a conventional powertrain to a computerized simulation using AVL Cruise software," Univ. Pitesti. Sci. Bull. - Automot. Ser., vol. 28, no. 1, Jan. 2018, doi: 10.26825/bup.ar.2018.003.

[22] G. Canbolat and H. Yaşar, "Performance Comparison for Series and Parallel Modes of a Hybrid Electric Vehicle," Sak. Univ. J. Sci., vol. 23, no. 38708, pp. 1-1, 2019, doi: 10.16984/saufenbilder.369149.

[23] A. C. R. Teixeira and J. R. Sodré, "Impacts of replacement of engine powered vehicles by electric vehicles on energy consumption and CO2 emissions," Transp. Res. Part D Transp. Environ., vol. 59, pp. 375-384, 2018, doi: 10.1016/j.trd.2018.01.004.

[24] D. R. Zamora, J. M. L. Martínez, C. J. L. Carrasco, and J. J. D. Vaca, "Development of an in-series hybrid urban bus model and its correlation with on-board testing results," World Electr. Veh. J., vol. 6, no. 2, pp. 405-415, 2013, doi: 10.3390/wevj6020405.

[25] F. Um, M. Allah, M. Bica, and D. Tutunea, "Analysis of Range Extended Hybrid Vehicle with Rotary Internal Combustion Engine Using AVL Cruise," pp. 217-224, 2019, doi: 10.1007/978-3319-94409-8.

[26] A. Dimaratos, D. Tsokolis, G. Fontaras, S. Tsiakmakis, B. Ciuffo, and Z. Samaras, "Comparative Evaluation of the Effect of Various Technologies on Light-duty Vehicle CO2 Emissions over NEDC and WLTP," Transp. Res. Procedia, vol. 14, pp. 3169-3178, 2016, doi: 10.1016/j.trpro.2016.05.257.

[27] B. Ciuffo and G. Fontaras, "Models and scientific tools for regulatory purposes: The case of CO2 
International Journal of Engineering and Management Sciences (IJEMS) Vol. 5. (2020). No. 2

DOI: 10.21791/IJEMS.2020.2.35.

emissions from light duty vehicles in Europe," Energy Policy, vol. 109, no. November 2016, pp. 76-81, 2017, doi: 10.1016/j.enpol.2017.06.057.

[28] V. Co, "Comparative Evaluation of the Effect of Various Technologies on Light-duty Comparative evaluation of the effect of various technologies on light-duty vehicle CO 2 emissions over NEDC and WLTP," Transp. Res. Procedia, vol. 14, no. July, pp. 3169-3178, 2016, doi: 10.1016/j.trpro.2016.05.257.

[29] A. Iorga, “VEHICLE MODEL SERIES WITH HYBRID,” no. 25, 2016.

[30] K. Liu et al., "Effect of asynchronous valve timing on combustion characteristic and performance of a high speed SI marine engine with five valves," Energy Convers. Manag., vol. 123, pp. 185199, 2016, doi: 10.1016/j.enconman.2016.06.042.

[31] Q. Zhang, N. Cui, K. Li, Y. Shang, and C. Zhang, "Co-simulation of energy management strategy for hybrid electric vehicle in AVL InMotion," Proc. - 2017 Chinese Autom. Congr. CAC 2017, vol. 2017Janua, no. April 2019, pp. 4932-4937, 2017, doi: 10.1109/CAC.2017.8243653.

[32] B. Wahono, W. B. Santoso, A. Nur, and Amin, "Analysis of range extender electric vehicle performance using vehicle simulator," Energy Procedia, vol. 68, pp. 409-418, 2015, doi: 10.1016/j.egypro.2015.03.272.

[33] M. I. Khan, M. Shahrestani, T. Hayat, A. Shakoor, and M. Vahdati, "Life cycle (well-to-wheel) energy and environmental assessment of natural gas as transportation fuel in Pakistan," Appl. Energy, vol. 242, no. March, pp. 1738-1752, 2019, doi: 10.1016/j.apenergy.2019.03.196.

[34] D. R. Cassiano, J. Ribau, F. S. A. Cavalcante, M. L. M. Oliveira, and C. M. Silva, “On-board Monitoring and Simulation of Flex Fuel Vehicles in Brazil," Transp. Res. Procedia, vol. 14, pp. 3129-3138, 2016, doi: 10.1016/j.trpro.2016.05.253.

[35] B. Wahono, A. Nur, W. B. Santoso, and A. Praptijanto, "A comparison study of range-extended engines for electric vehicle based on vehicle simulator," J. Mech. Eng. Sci., vol. 10, no. 1, pp. 1803-1816, 2016, doi: 10.15282/jmes.10.1.2016.5.0173.

[36] C. D. Iclodean and C. D. Iclodean, "Energetic efficiency evaluation of the Lunar Roving vehicles using computer simulation,” TEM J., vol. 7, no. 4, pp. 937-943, 2018, doi: 10.18421/TEM74-35.

[37] H. T. Arat, "Simulation of diesel hybrid electric vehicle containing hydrogen enriched CI engine," Int. J. Hydrogen Energy, pp. 10139-10146, 2019, doi: 10.1016/j.ijhydene.2018.10.004.

[38] B. Norbert, V. Bogdan-Ovidiu, M. Dan, C. Aron, and K. Dimitrios, "Analysis of Range Extended Hybrid Vehicle with Rotary Internal Combustion Engine Using AVL Cruise,” 2019.

[39] M. Imre and V. Zolt, “„IFFK 2012” Budapest, 2012. augusztus 29-31. Elektromos meghajtású járművek menetdinamikai szimulációja," pp. 149-152, 2012.

[40] A. Praptijanto, W. B. Santoso, A. Nur, B. Wahono, and Y. Putrasari, "Performance and driveline analyses of engine capacity in range extender engine hybrid vehicle," in AIP Conference Proceedings, 2017, doi: 10.1063/1.4968254. 
[41] X. Fu, Q. Zhang, J. Tang, and C. Wang, "Parameter matching optimization of a powertrain system of hybrid electric vehicles based on multi-objective optimization," Electron., vol. 8, no. 8, pp. 710, 2019, doi: 10.3390/electronics8080875.

[42] N. Euler-Rolle, C. H. Mayr, I. Škrjanc, S. Jakubek, and G. Karer, "Automated vehicle driveaway with a manual dry clutch on chassis dynamometers: Efficient identification and decoupling control," ISA Trans., no. xxxx, 2019, doi: 10.1016/j.isatra.2019.08.021.

[43] M. Montazeri-Gh and A. Fotouhi, "Traffic condition recognition using the k-means clustering method," Sci. Iran., vol. 18, no. 4 B, pp. 930-937, 2011, doi: 10.1016/j.scient.2011.07.004.

[44] A. Farshidianfar, M. Ebrahimi, H. Rahnejat, M. T. Menday, and M. Moavenian, "Optimization of the high-frequency torsional vibration of vehicle driveline systems using genetic algorithms," Proc. Inst. Mech. Eng. Part KJ. Multi-body Dyn., vol. 216, no. 3, pp. 249-262, Sep. 2002, doi: 10.1177/146441930221600305.

[45] T. Resch, M. Sopouch, T. Resch, and P. Herster, "Analysis of Gearbox Acoustics with AVL EXCITE," no. June, 2016. 